\title{
The changing concept of competence and categorisation of learning outcomes in Europe: Implications for the design of higher education radiography curricula at the European level
}

\author{
Joseph Castillo ${ }^{\mathrm{a}, *}$, Carmel J. Caruana ${ }^{\mathrm{b}}$, David Wainwright ${ }^{\mathrm{c}}$ \\ ${ }^{a}$ Medical Imaging Department, Mater Dei Hospital, Msida, Malta \\ ${ }^{\mathrm{b}}$ Biomedical Physics, Faculty of Health Sciences, University of Malta, Msida, Malta \\ ${ }^{\mathrm{c}}$ Work, Health and Wellbeing Research Group, University of Bath, Claverton Down, Bath BA2 7AY, UK
}

\section{A R T I C L E I N F O}

\section{Article history:}

Received 19 November 2010

Received in revised form

22 December 2010

Accepted 28 December 2010

Available online xxx

\section{Keywords:}

Competence

Competency

Curriculum development

Learning outcomes

Qualification frameworks

Radiography competences

\begin{abstract}
A B S T R A C T
The Bologna process has made the qualifications framework of the European Higher Educational Area based on three cycles and on learning outcomes central to curriculum development in higher education in Europe. The Tuning Educational Structures in Europe project recommended that learning outcomes be expressed in terms of competences. The expression of educational programme learning outcomes as inventories of competences has since become the norm at the European level. However, the more recent European Qualifications Framework for lifelong learning utilises a tripartite set of categories of learning outcomes, namely, knowledge, skills and competence. In addition, the definition of competence used though overlapping with that used by Tuning, is however not identical. This article reviews and discusses the changing definition of the concept of competence and changes in categorisation of learning outcomes in Europe and their potential impact on curriculum development in radiography at the European level. It is proposed that the shift in the definition of competence and in the categorisation of learning outcomes should be taken into account in the formulation of new European curricula or the updating of present ones so that they may reference in a more direct manner to the levels of the European Qualifications Framework.
\end{abstract}

(c) 2011 The College of Radiographers. Published by Elsevier Ltd. All rights reserved.

\section{Introduction}

The rapid advances in technology, shortage of radiologists, changes in healthcare policies and continuous professional development (CPD) requirements have had an impact on radiography education in most countries where the profession is sufficiently well developed. ${ }^{1-9}$ In addition, in Europe, curriculum developers are expected to structure educational programmes so as to facilitate student and worker mobility. A prerequisite for all this would be the development of qualification and curricular frameworks based on European recommendations. European thematic networks have aligned their curriculum development with the recommendations of the European Higher Education Area (EHEA) qualifications framework (QF-EHEA) which is based on three levels (called 'cycles') and on agreed learning outcomes expressed as competences as recommended by the Tuning Educational Structures in Europe project. ${ }^{10-12}$ However, the more recent European Qualifications Framework (EQF) for lifelong

\footnotetext{
* Corresponding author. Tel.: +35621667656

E-mail address: josecast@go.net.mt (J. Castillo).
}

learning utilises a tripartite set of categories of learning outcomes, namely, knowledge, skills and competence. In addition, the definition of competence used in the EQF though very much overlapping with that used by Tuning is not identical. This article reviews the changes in the definition of the concept of competence and the categorisation of learning outcomes in Europe and their potential impact on the design of curriculum documents in higher education (HE) at the European level. The authors put forward recommendations for radiography curriculum developers.

\section{Materials and methods}

Information was searched for in the English language databases Medline, Web of Knowledge, Embase and Cinahl using the key words: 'learning outcomes', 'competence', 'radiography education', 'European higher education area', 'Bologna process', and 'qualifications frameworks'. Important sources of information regarding European recommendations were the official websites for education and training of the European Commission, ${ }^{13}$ the Bologna Process $^{14}$ and Tuning. ${ }^{15}$ 


\section{The concept of competence: variable definition and terminology}

The concept of competence is derived from the Latin competens, which means capable or qualified. ${ }^{16}$ White ${ }^{17}$ is credited with having introduced the term to describe those personality characteristics associated with superior performance and high motivation. McClelland ${ }^{18}$ followed this approach and developed tests to predict competence as opposed to intelligence. Since then several definitions and approaches to the concept of competence have been proposed and there is a general lack of consensus over the meaning and use of the term. ${ }^{19-22}$ To add to the ambiguity, articles in the educational literature present two spellings of the word, namely, 'competence' and 'competency' offering the same meaning to each with their respective plurals 'competences' and 'competencies' readily interchangeable. The first form of the word is in general used in the EHEA and Tuning documentation and the second in documentation from the US, Canada, Australia and New Zealand. ${ }^{20}$ Some authors and organisations from the professional literature propose a distinction between 'competence' and 'competency'. For example, the Chartered Institute of Personnel and Development (UK) offers the following distinction ${ }^{23}$ :

"Competency is now generally defined as the behaviours that employees must have, or must acquire, to input into a situation in order to achieve high levels of performance, while competence relates to a system of minimum standards or is demonstrated by performance and outputs"

Woodruffe ${ }^{24}$ provides a similar distinction:

"A competency is the set of behaviour patterns that the incumbent needs to bring to a position in order to perform its tasks and functions with competence"

The inference here is that 'competency' is a level of behavioural excellence to aspire to, whilst 'competence' is simply a statement of minimum observable performance which is considered acceptable.

Rowe $^{25}$ makes a distinction between behaviours that are cognitively based and those that reflect personal values. In the cognitive category Rowe includes problem solving, decisionmaking, strategic thinking, and working with information whilst personal values include honesty, integrity, commitment and courage. Delamere le Deist and Winterton suggested an overarching framework in which cognitive, functional, social and metacompetences are combined and viewed in holistic terms so that a combination of competences is something more than the sum of the individual competences. ${ }^{21,26}$

In Europe, the various definitions of competence found in the research literature and other educational documents from UK, France and Germany were used by the Bologna Working Group in Europe to suggest that competence includes:

(i) cognitive competence involving the use of theory and concepts, as well as informal tacit knowledge gained experientially,

(ii) functional competence (skills or know-how) referring to those activities that a person should be able to do when functioning in a given area of work, learning or social activity,

(iii) personal competence involving knowing how to conduct oneself in a specific situation, and

(iv) ethical competence involving the possession of certain personal and professional values. ${ }^{10}$

In a later document leading to the EQF recommendations, the terminology was simplified: 'cognitive competence' was termed 'knowledge', functional competence was termed 'skills' and personal and ethical competences were combined into a single category termed 'wider competences'. The wider competences included autonomy and responsibility, learning competence, communication and social competence and professional and vocational competence. ${ }^{27}$ However in the final EQF recommendations the term "wider competence' was dropped in favour of the simpler term 'competence'. The definition of competence in the EQF places emphasis on the terms 'responsibility' and 'autonomy' which reflects the importance of these concepts in work and study situations in which practitioners assume responsibility in an autonomous manner for their professional practice and also for their own learning. ${ }^{28-30}$

\section{Practical approaches to competence}

Gonczi $^{31}$ describes three practical approaches to competence. The first approach is referred to as task-based, functional or behaviourist where tasks are broken down into discrete behaviours that can be observed and assessed. In this way, the task becomes synonymous with the competence and is usually defined as, something a person should be able to do. ${ }^{32}$ Its focus is more on objectively observable performance than on knowledge and it is concerned more with what people can demonstrate rather than with what they know. ${ }^{33}$ This approach which is favoured by employers ${ }^{19,21}$ has been criticised by health professions educators as being too reductionist, ignores the complexity of performing in real world situations and reduces the role of professional judgement in quality performance. ${ }^{34}$ In addition, there is a concern that the humanistic aspects of care such as empathy will be eclipsed by the strictly technical aspects of healthcare which are easier to observe, demonstrate and assess. ${ }^{35}$ The second approach refers to generic competences and concentrates on psychological and personality attributes of the practitioner that are crucial to effective performance. Generic competences such as critical thinking and problem-solving skills are transferable to different situations and professional work. However, doubts have been raised as to whether certain generic competences can be assessed effectively. ${ }^{36}$ The third approach is a marriage between the functionalist and generic approaches applied to the context in which they are employed. Thus, complex combinations of knowledge, skills, values and attitudes are utilised to understand particular situations in which professionals may find themselves. This holistic view shifts the emphasis from specific observable tasks towards the purpose of the work or educational activity. ${ }^{37,38}$ This outlook has been adopted by many radiography institutions where the assessment of radiography competences is designed to encompass all the above facets of competence as students progress through their studies. ${ }^{39-42}$

\section{The European Higher Education Area Qualifications Framework (QF-EHEA)}

The Bologna process seeks to create a European Higher Education Area (EHEA), harmonise European qualifications, foster the mobility of workers and students, the employability of graduates and assist the future development of Europe. Amongst the central features of the process is the structuring of higher educational qualifications based on three levels called 'cycles' (1st cycle Bachelor, 2nd cycle Masters and 3rd cycle Doctorate). The 'Tuning Educational Structures in Europe' programme is a university driven project, which aims to offer a concrete approach to implementing the Bologna agreement at the HE level and in particular subject areas such as Radiography. Tuning requires educational institutions to promote student-centred curriculum development based on agreed cycle learning outcomes expressed in terms of competences. ${ }^{12}$ Although learning outcomes are formulated by staff these should be designed from the point of view of the student. It is indeed this feature that distinguishes learning outcomes from 


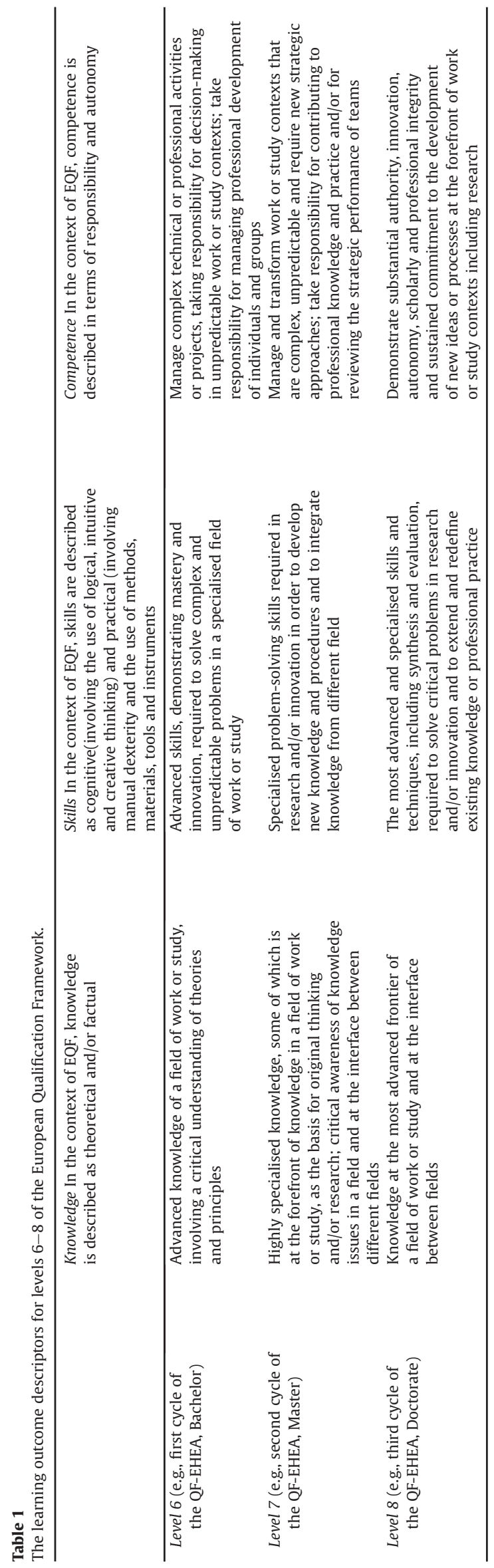

conventional teaching objectives which are written from the point of view of the teaching staff. Learning outcomes are to be acquired by the student (this is implied by the word 'learning' in 'learning outcome') and their acquisition by the student facilitated by the academic/clinical staff. The EQ-EHEA recognises only one type of learning outcome which is 'competence'. This explains why in Tuning documents 'learning outcomes' and 'competences' are often seen as synonymous. These competences are to be determined through the involvement of all stakeholders. Competence is defined by Tuning as "a dynamic concept that integrates knowledge, skills, abilities, values and attitudes, the development of which enables the learner to perform effectively, to be able to recognise and respond to change and to treat service users appropriately". ${ }^{43}$ This definition indicates that the project leaders were aiming at the holistic approach to competence described by Gonczi. ${ }^{37}$ The Tuning leaders proposed that competences be classified in two categories namely Generic and Subject Specific. Generic competences are defined by Tuning as those skills which are transferable across professions and which are considered to be particularly important to employability and citizenship whilst subject specific competences are specific to particular professions. ${ }^{12}$ The Generic competences are further subdivided into three types namely instrumental, interpersonal and systemic whereas the Subject Specific competences can be divided into subcategories as decided by the different professions.

To address the problem of variability of radiography education in Europe and its impact on mobility the Higher Education Network for Radiography in Europe (HENRE) ${ }^{44}$ has published an inventory of agreed Generic and Subject Specific competences for the first cycle of radiography (diagnostic and therapy) education. ${ }^{43}$ HENRE did not develop any Generic or Subject Specific competences for the second and third cycles. However, Caruana and Plasek, ${ }^{45}$ did develop inventories for the imaging physics component of radiography education (including inventories for the second and third cycle) in conjunction with HENRE.

\section{The European Qualification Framework for lifelong learning}

In 2006, the European Commission launched the European Qualifications Framework for lifelong learning. ${ }^{11}$ The EQF is organised into eight levels that span the whole spectrum of education from basic to doctoral level. ${ }^{46}$ The EQF builds on the successful policy goals of the EHEA, such as the consistency in the design of qualifications and extends it to all levels of education. In the EQF the first cycle of the EHEA (Bachelor) is classified at level 6, the second cycle (Master) at level 7 whilst the third cycle (Doctorate) is at level 8. It is hence important to note that it is possible to develop programmes which are compatible with both qualification frameworks. It should be noted that that HE programmes are only one means of reaching levels $6-8$ and the EQF recognises (in the spirit of lifelong learning) that these levels can also be reached through informal and non-formal learning. By 2012 each EU member state is required to develop its own national qualification framework (NQF) in accordance with national legislation and practice and reference it to the EQF. Three countries (Malta, Ireland and UK) have referenced their NQF to the EQF. ${ }^{47-51}$

The EQF recognises three types of learning outcomes for each level namely knowledge, skill and competence learning outcomes. This is in contrast to the single category 'competences' of the QFEHEA. ${ }^{52}$ In the EQF, knowledge is defined as "The outcome of the assimilation of information through learning. Knowledge is the body of facts, principles, theories and practices that is related to a field of work or study. In the context of the European Qualifications Framework, knowledge is described as theoretical and/or factual"; skill is defined as "the ability to apply knowledge and use know-how to complete tasks 
and solve problems. In the context of the European Qualifications Framework, skills are described as cognitive (involving the use of logical, intuitive and creative thinking) or practical (involving manual dexterity and the use of methods, materials, tools and instruments)"; competence is defined as "the proven ability to use knowledge, skills and personal, social and/or methodological abilities, in work or study situations and in professional and personal development. In the context of the EQF, competence is described in terms of responsibility and autonomy". Table 1 shows the descriptors for the knowledge, skills and competence learning outcomes at each of levels $6-8$.

\section{Consequences of the adoption of the EQF for radiography education}

The major significance of the EQF is that finally the educational community in Europe has a single set of agreed definitions and categorisation of learning outcomes to use in curriculum development at the European level (and the national level if so desired). This will go a long way towards reducing the uncertainty arising from the confusing plurality of definitions and approaches to competence to be found in the literature. In addition, the categorisation of learning outcomes into knowledge, skills and competence means that all of these categories of learning outcomes will be given their due importance. On the other hand it does imply that European curricular documents such as the HENRE Tuning Template for Radiography $^{53}$ and those of Caruana and Plase ${ }^{45}$ which are based solely on competences need to be partially rewritten so that they may reference in a more direct manner to the knowledge-skills-competence approach of the EQF. Learning outcomes of programmes such as the European Masters Programme in Medical Imaging (EMPIMI) project (which does refer to the EQF in its documentation) ${ }^{54}$ will also need to be partially re-formulated.

One of the aims of the EQF is to bridge the gap between vocational education \& training (VET) and HE. ${ }^{55,56}$ Since not all European countries require radiographers to be qualified at HE level such a link would help bring Radiography in Europe into an all graduate profession. Through use of the EQF level descriptors, radiography curriculum developers in such states can develop link programmes from level 5 (VET) to level 6 (HE), thus enabling learners to make the transition from VET to HE. This can be achieved partially through recognition of the non-formal and informal learning which candidates would have acquired through experiential learning and CPD activities. Indeed, a detailed European profile of the radiography profession based on the EQF would make the recognition of non-formal and informal learning much easier. The general issue of transition from VET to HE requires research if present difficulties are to be overcome. ${ }^{51,56}$

The adoption of a European general radiography curriculum based on the EQF by the radiography profession can also facilitate the recognition of cross-border radiography qualifications on the basis of "coordination of minimum training conditions" as recommended by European Directive 2005/36/EC. ${ }^{57}$ Paragraph 29 of the preamble to the directive states that: "Where a national and European-level professional organisation or association for a regulated profession makes a reasoned request for specific provisions for the recognition of qualifications on the basis of coordination of minimum training conditions, the Commission shall assess the appropriateness of adopting a proposal for the amendment of this Directive".

\section{Conclusion and recommendations}

The plethora of definitions attributed to the concept of competence and the various classifications of learning outcomes have in the past created difficulties for curriculum developers. The EC recommendations contained in the EQF for lifelong learning have helped to reduce the ambiguity. Curriculum developers can use the EQF recommendations to create robust curricular documents, which would facilitate mobility for students and professionals across Europe. It is suggested that:

- A detailed competence profile for European radiography be developed which is referenced directly to EQF levels and which would help bridge the gap between VET and HE in states where radiography education is not yet totally $\mathrm{HE}$ based.

- The learning outcomes contained within the HENRE Tuning Template for undergraduate radiography and those of the EMPIMI Master's programme are partially rewritten to reflect the knowledge, skills and competence approach of the EQF and the modified definition of competence formulated by the EQF.

\section{References}

1. Brealey SD, King DG, Hahn S, Crowe M, Williams P, Rutter P, et al. Radiographers and radiologists reporting plain radiograph requests from accident and emergency and general practice. Clinical Radiology 2005;60(6):710-7.

2. Smith T, Yielder J, Ajibulu O, Caruana E. Progress towards advanced practice roles in Australia, New Zealand and the Western Pacific. Radiography 2008;14 (Suppl. 1):e20-3.

3. Smith TN, Baird M. Radiographers' role in radiological reporting: a model to support future demand. Medical Journal of Australia 2007;186(12):629-31.

4. Cowling C. A global overview of the changing roles of radiographers. Radiography 2008;14(Suppl. 1):e28-32.

5. The Society of Radiographers. Research and the Radiography Profession. A strategy and five year plan. Available from: http://www.sor.org/public/pdf/research/ strat_fiveyr.pdf; 2005 [cited 2010 22nd December].

6. Forsyth LI, Robertson EM. Radiologist perceptions of radiographer role development in Scotland. Radiography 2007;13(1):51-5.

7. Brealey S, King DG, Hahn S, Godfrey C, Crowe MTI, Bloor K, et al. The costs and effects of introducing selectively trained radiographers to an A\&E reporting service: a retrospective controlled before and after study. British Journal of Radiology 2005;78(930):499-505.

8. Jensch S, van Gelder RE, Florie I, Thomassen-De Graaf MA, Lobe IV, Bossuyt PMM, et al. Performance of radiographers in the evaluation of CT colonographic images. American Journal of Roentgenology 2007;188 (3):W249-55.

9. Larsson W, Aspelin P, Bergquist M, Hillergård K, Jacobsson B, Lindsköld L, et al. The effects of PACS on radiographer's work practice. Radiography 2007;13 (3):235-40.

10. Bologna Working Group. A framework for qualifications of the European higher education area. Available from: http://www.bologna-bergen2005.no/Docs/00Main_doc/050218_QF_EHEA.pdf; 2005 [cited 2010 3rd June].

11. European Parliament and Council. Recommendation 2008/C 111/01 on the establishment of the European Qualifications Framework for lifelong learning. Official Journal of the European Union; 6.5.2008.

12. Gonzales J, Wagenaar R, editors. Universities' contribution to the Bologna process. 2nd ed. Publicaciones de la Universidad de Duesto; 2008.

13. European Commission. Education and training. Available from: http://ec.europa. eu/education/index_en.htm; 2010 [cited 2010 May].

14. Bologna process. Official Bologna process website. Available from: http://www. ond.vlaanderen.be/hogeronderwijs/bologna/; 2010 [cited 2010 May]

15. European Commission. Tuning educational structures in Europe. Available from: http://tuning.unideusto.org/tuningeu/; 2000 [cited 2010 May].

16. Mulder M. Competence development - some background thoughts. The Journal of Agricultural Education and Extension 2001;7(4):147-58.

17. White RW. Motivation reconsidered - the concept of competence. Psychological Review 1959;66(5):297-333.

18. McClelland DC. Testing for competence rather than for intelligence. American Psychologist 1973;28(1):1-14.

19. Winterton J, Delamare-Le Deist F, Stringfellow E. Typology of knowledge, skills and competences: clarification of the concept and prototype. Centre for European Research on Employment and Human Resources; 2005. pp. 1-108.

20. Sultana R. Competence and competence frameworks in career guidance: complex and contested concepts. International Journal for Educational and Vocational Guidance 2009;9(1):15-30.

21. Delamare-Le Deist F, Winterton J. What is competence? Human Resource Development International 2005;8(1):27-46.

22. Westera W. Competences in education: a confusion of tongues. Journal of Curriculum Studies 2001;33(1):75-88.

23. Hogg C. Competency and competency framework. Available from: http://www. cipd.co.uk/subjects/perfmangmt/competnces/comptfrmwk.htm; 2009 [cited 2010 25th April].

24. Woodruffe C. What is meant by a competency? Leadership \& Organization Development Journal 1993;14(1):29-36. 
25. Rowe C. Clarifying the use of competence and competency models in recruitment, assessment and staff development. Industrial and Commercial Training 1995;27(11):12-25.

26. Semeijn JH, van der Velden R, Heijke H, van der Vleuten $C$, Boshuizen HPA et al. Competence indicators in academic education and early labour market success of graduates in health sciences. Journal of Education and Work 2006;19 (4):383-413.

27. Commission of the European Communities. Commission staff working document Towards a European Qualifications Framework for lifelong learning. Available from: http://www.feani.org/webfeani/Statements\%20EQF/EQF-EN-final\%20version\% 20-PDF.PDF; 2005 [cited 2010 11th August].

28. Williams PL. Using theories of professional knowledge and reflective practice to influence educational change. Medical Teacher 1998;20(1):28-34.

29. Gillie Bolton. Reflective practice, writing and professional development. 3rd ed. Sage; 2010.

30. Hardy. Role extension and role advancement - is there a difference? A discussion paper. Radiography 2006;12(4):327-31.

31. Gonczi A. Competency based assessment in the professions in Australia. Assessment in Education: Principles, Policy \& Practice 1994;1(1):27-44.

32. Mitchell BML. Towards a competent workforce. Gower; 1996. p. 352

33. Smith MK. 'Competence and competencies'. The encyclopaedia of informal educa tion. Available from: www.infed.org/biblio/b-comp.htm; 1996 [cited 2010 24th May].

34. Milligan F. Defining and assessing competence: the distraction of outcomes and the importance of educational process. Nurse Education Today 1998;18 (4):273-80.

35. Cowan DT, Norman I, Coopamah VP. Competence in nursing practice: a controversial concept - a focused review of literature. Nurse Education Today 2005;25(5):355-62.

36. McMullan M, Endacott R, Gray MA, Jasper M, Miller CML, Scholes J, et al. Portfolios and assessment of competence: a review of the literature. Journal of Advanced Nursing 2003;41(3):283-94.

37. Gonczi, A., A competency-based approach to initial and continuing professional education. Training and Professional Development in Adult and Continuing Education, 1994(1): pp. 40-47.

38. Sandberg J. Understanding human competence at work: an interpretative approach. The Academy of Management Journal 2000;43(1):9-25.

39. Burchell $\mathrm{H}$. Facilitating action research for curriculum development in higher education. Innovations in Education and Training International 2000;37 (3):263-9.

40. Ng CKC, White P, McKay IC. Establishing a method to support academic and professional competence throughout an undergraduate radiography programme. Radiography 2008;14(3):255-64.

41. Williams PL, Berry JE. What is competence? A new model for diagnostic radiographers: part 1. Radiography 1999;5(4):221-35.

42. Williams PL, Berry JE. What is competence? A new model for diagnostic radiographers: part 2. Radiography 2000;6(1):35-42.
43. Challen V. Radiography tuning template, in Socrates Erasmus; 2008.

44. Higher Education Network for Radiography in Europe. Home page. Available from: http://www.henre.co.uk/; 2001 [cited 2010 April].

45. Caruana CJ, Plasek J. An inventory of biomedical imaging physics elements-ofcompetence for diagnostic radiography education in Europe. Radiography 2006;12(3):189-202.

46. European Commission and Directorate-General for Education and Culture. The European qualification framework for lifelong learning. Available from: http:// bookshop.europa.eu/is-bin/INTERSHOP.enfinity/WFS/EU-Bookshop-Site/en_GB/-/ EUR/ViewPublication-Start?PublicationKey=NC3008272; 2008 [cited 2010 15th August].

47. Malta Qualification Council. Referencing handbook 2010. Available from: http:// www.mqc.gov.mt/referencinghandbook2010?|=1; 2009 [cited 2010 14th August].

48. Malta Qualification Council. Referencing of the Malta Qualifications Framework $(M Q F)$ to the European Qualifications Framework (EQF) and the Qualifications Framework of the European Higher Education Area (QF/EHEA). Available from: http://www.mqc.gov.mt/referencingreport?|=1; 2009 [cited 2010 15th August].

49. European Commission. Referencing to EQF: Irish and Maltese experience. EQF Newsletter. Available from: http://ec.europa.eu/education/lifelong-learningpolicy/doc/eqf/news1_en.pdf; 2010 April.

50. The Qualifications and Curriculum Authority. Referencing the qualifications frameworks of the United Kingdom to the European Qualifications Framework. Available from: http://www.scqf.org.uk/News/LatestNews/NewPublicationUKQu alificationsFrameworksEQFReferencingReport.aspx; 2010 [cited 2010 14th August].

51. Mike Coles. Making the European learning area a reality. Realizing the European learning area. Available from: http://www2.warwick.ac.uk/fac/soc/ier/glacier/ qual/eqf/mike_coles_eqf.pdf; 3-5 June, 2007 [cited 2010 16th August].

52. European Commission. Overarching framework of qualifications of the EFEA. Available from: http://www.ond.vlaanderen.be/hogeronderwijs/bologna/qf/ overarching.asp; 2009 [cited 2010 22nd December].

53. Harris P, Vinorum A, Henner A, Lanca L, Graciano P, Vieira L, et al. Tuning template for radiography in Europe. Available from: http://tuning.unideusto.org/ tuningeu/images/stories/template/Radiography.pdf; 2008 [cited 2010 16th August].

54. EMPIMI. Intended learning outcomes. Available from: http://www.empimi.eu// study/intended.pdf. [cited 201002 June].

55. Hayward Geoff et al, Degrees of success: the transition between VET and HE: Full Research Report. 2008, ESRC End of Award Report: Swindon: ESRC.

56. Calleja J. Linking VET and higher education. Is the EQF contributing to this issue ? European Journal of Vocational Training; 2008:156-66. 2007/3-2008/1(42/43).

57. European Parliament \& Council of the European Union. Directive 2005/36/EC of the European Parliament and of the Council of 7 September 2005 on the recognition of professional qualifications. Available from: http://eur-lex.europa.eu/ LexUriServ/LexUriServ.do?uri=OJ:L:2005:255:0022:0142:en:PDF; 2005 [cited 2010 9th August]. 